\title{
Readiness of Polytechnic Manufacturing Program in Malaysia towards Future Industry
}

\author{
Nurul Afizah Adnan, Aini Nazura Paimin, Abdullah Azraai Hasan
}

\begin{abstract}
Polytechnic education was introduced in Malaysia with funding from the World Bank in 1969. The purpose is to be one of Malaysia's education provider to access quality in produce holistic, enterprising and competitive human capital in line with global industrial needs. Currently, there are 37 polytechnics in they that offered quality programs with relevant curriculum. One of the programs is Diploma in Mechanical Engineering (Manufacturing) is competent skills in the field of mechanical engineering to fulfill the demand of workers in the engineering manufacturing sector. For remain competitive especially in terms of future technology advancement, this program needs to be revised so that the students who are produced can meet the requirements of the future industry specially to face the challenging in Industrial Revolution 4.0(IR4.0). To get the clear situation, the qualitative study had been conducting with the interview method to identify how far the adequate of polytechnic manufacturing program towards IR4.0 regarding the readiness of student competency, the effect of the changes and actions taken by polytechnics management. From the findings, it shown that the manufacturing programs in Polytechnic Malaysia need to arrange the strategy to make sure the student or the graduates that they develop can fulfil IR4.0 skills and competencies related.
\end{abstract}

Keywords: Readiness, Manufacturing, Polytechnic, Future Industry, Industrial Revolution 4.0.

\section{INTRODUCTION}

Manufacturing are usually related to machines that convert raw materials into new products. A study by [1] has also explained that the manufacturing sector in Malaysia is very broad. Regarding of explosion of IR4.0, the manufacturing sector that occurred due to technological developments will be involved with 3D printing, simulation, big data and in the real time vision. As example the development online sales services such as car services, home medical checks, food orders sent directly from the store to refrigerator, and so on [2]. This had a direct impact on the development of this engineering field in the future as well as involving full automation process and the involvement of the use of Internet of Things (IoT). This electronics technology that will be applied in the field of manufacturing and services to upgrade the manufacturing process totally [3].

Revised Manuscript Received on December 30, 2019.

* Correspondence Author

Nurul Afizah Adnan*, FPTV, Universiti Tun Hussein Onn, Johor, Malaysia. E-mail: nurulresearch2017@gmail.com

Aini Nazura Paimin, Lecturer, FPTV, Universiti Tun Hussein Onn, Johor, Malaysia. E-mail: nazura@uthm.edu.my

Abdullah Azraai Hasan, FPTV, Universiti Tun Hussein Onn, Johor, Malaysia E-mail: azraaihasan@gmail.com

(C) The Authors. Published by Blue Eyes Intelligence Engineering and Sciences Publication (BEIESP). This is an open access article under the CC BY-NC-ND license (http://creativecommons.org/licenses/by-nc-nd/4.0/)
In understanding this future IR4.0 scenario, it is important to evaluate the education system in the country to meet future human capital requirements. Based on the trend, IR4.0 will require major changes in key aspects of education that include curriculum content, pedagogy, teaching \& learning and education structure / management. In terms of curriculum implementation. IR4.0 is expected to demand changes not only in the core content of the discipline but also the general content of the program [4]. This is because new emphasis should be given to specific skills and new content should be added and explored. Existing education programs need to be improved while new programs need to be developed to meet the demands of the already vague and changing industry market. It can affect the program offered in education line. In polytechnic, the Diploma of Mechanical Engineering (Manufacturing) program offered as a program with the part of a mechanical discipline engineering program that focuses on manufacturing. Core discipline courses are engineering drawings, computer-based designs, electrical technology in enhancing student knowledge and ability to basic mechanical engineering. In order to increase knowledge on the field of manufacturing, specialized courses such as manufacturing systems, manufacturing workshops, manufacturing controls, quality control, computer-assisted manufacturing, industrial robots and jigsaw courses, fixtures and tooling are taught and included in curriculum. For this purpose, the course offered need to be revised regarding the future requirements. In the IR 4.0 era, jobs that require creativity are likely to remain $[3,6]$. Therefore, the development of IR4.0 needs to be in tandem with Education line so that it creates the next generation of creative graduates with the ability to think critically and develop an innovation.

\section{LITERATURE REVIEW}

In applying the field of manufacture in education, there is a Model of Four Pillar in Manufacturing Program that was developed in 2011[5]. It has provided a clear graphical picture of the core content of the manufacturing program that needs to be applied in the development of the curriculum for this field. However, the plan is a tailor-made proposal to form an assessment plan that features an academic curriculum with the industry that needs to be implemented especially in era IR4.0. The development of the IR4.0 may be new to us in Malaysia. But the handler for this revolutionary revolution, demands us to change for ensure continuous progress can be achieved [7]. 
The chronological development of the industrial revolution began with the first Industrial Revolution that focused on the use of steam-powered machines. Then secondly it involves with electricity to change the assembly line.

The third development is the use of information technology (IT) and the fourth is further automate production lines [3], [4]. Next to the IR4.0 that involves a comprehensive physical-system system and is expected to create a new working environment, to meet the rapid growth of existing markets, especially in introducing new products and services [1]. Therefore, this study focuses to get the clear on the valuable insight from the expert in polytechnic to relate with the research question below:

1) What the student competency and relate its requirements to the Revolution Industry 4.0 transformation mentioned today?

2) What is the effect of the change that will result from the development of this revolution in the field of manufacturing especially in the context of employment involving students or graduates of polytechnics in this field?

3) What is the educational system (specifically polytechnic as TVET provider) today ready to face the challenge of the Industrial Revolution 4.0? If not, what should they do?

\section{METHODOLOGY/MATERIALS}

In this phase, the researcher will set up a set of an interview questions that contain interview protocols in the form of semi-structured questions to be interviewed. According to [8] finding an interview is a qualitative way of collecting data that is very useful to know one event more clearly, validly and based on one's experience. In this study, the expert's interview will be used to obtain more information related research objectives. This qualitative study carried out an interview data collection method from the One (1) Head of Program, One (1) Head of Unit, One (1) Senior Lecturer and One (1) Lecturer from Polytechnic with background Manufacturing. Researchers need suggestions from assigned participants to give opinions and insights as possible.

The selected academic criteria are based on:

1) 10 years and above experience in teaching and learning for polytechnic related manufacturing program.

2) Has been involved as a Polytechnic program advisor, Program Head, Senior Lecture and Lecturer.

3) Has the advantage of developing program curriculum with industry.

Table- 1: List of participants involved

\begin{tabular}{|l|l|l|l|}
\hline \multirow{2}{*}{ No } & \multicolumn{3}{|l|}{ Information of participant } \\
\cline { 2 - 4 } & Participant & Experience & Position \\
\hline 1 & Participant A & 28 years & $\begin{array}{l}\text { Senior } \\
\text { Lecturer }\end{array}$ \\
\hline 2 & Participant B & 20 years & Head of Unit \\
\hline 3 & Participant C & 10 years & $\begin{array}{l}\text { Head of } \\
\text { Program }\end{array}$ \\
\hline 4 & Participant D & 10 years & Lecturer \\
\hline
\end{tabular}

\section{RESULT AND DISCUSSION}

Based on the question, the answer from the expert had been elaborate based on the expert views:

1) Student competency and relate to requirements the Revolution Industrial 4.0:

Table 2: Student competency

\begin{tabular}{|l|l|}
\hline Participant & Result \\
\hline A & $\begin{array}{l}\text { The student's competence in era } \\
\text { IR4.0 is new. The curriculum is still } \\
\text { included in the IR4.0 element. If we } \\
\text { want to see from nine pillars, it has } \\
\text { some pillar that we can associate } \\
\text { with our syllabus and part of that is } \\
\text { to look at what this industry is } \\
\text { doing. It goes beyond what the } \\
\text { industry and what we teach. So, for } \\
\text { me if we want to know student } \\
\text { competence, it must be related to } \\
\text { the existing facilities. If we want to } \\
\text { relate with IR4.0 we need to } \\
\text { understand the pillars. We can refer } \\
\text { to those tools if they are available, } \\
\text { if not we have to find a solution to } \\
\text { make sure we get what we need to } \\
\text { learn. One of the IR4.0 pillars were } \\
\text { a simulation. For simulations we } \\
\text { have already taught, we expose to } \\
\text { our student as examples of the } \\
\text { CADCAM subject, there are } \\
\text { simulations before we turn physical } \\
\text { products. That's an example of the } \\
\text { element we touch. Other examples } \\
\text { of cybersecurity, IoT and more. } \\
\text { There are elements we can fulfill } \\
\text { and some not. } \\
\text { Been as a competence or can justify } \\
\text { by ability of a student or individual } \\
\text { to perform the task he or she refers } \\
\text { to the knowledge he or she has. } \\
\text { There are also high-performing } \\
\text { students who can perform a variety } \\
\text { of multitasking tasks regarding } \\
\text { IR4.0 needed but there are also } \\
\text { students who may not have } \\
\text { achieved the level of multitasking } \\
\text { that he or she may be good at in one } \\
\text { thing but less in other. But there are } \\
\text { students who have reached the } \\
\text { multitasking level but, there are } \\
\text { students who are not cognitively } \\
\text { good, but he has psychomotor }\end{array}$ \\
\hline
\end{tabular}




\begin{tabular}{|c|c|}
\hline C & $\begin{array}{l}\text { First, we know the basic IR4.0 } \\
\text { pillar, out of the } 9 \text { pillars we have } \\
\text { implemented, among the most } \\
\text { common pillars we have } \\
\text { encountered is simulation. We are } \\
\text { in an academic line in this program } \\
\text { where our students are exposed to } \\
\text { simulations either through } \\
\text { AutoCAD, Mastercam, Inventor, to } \\
\text { simulate the machining process for } \\
\text { CNC Milling and Lathe Machine. } \\
\text { In addition, we use Automation for } \\
\text { PLC and Pneumatic System labs. } \\
\text { That's one of the areas we have } \\
\text { been working on for a long time. } \\
\text { We also focus on Additive } \\
\text { Manufacturing, Rapid Prototyping } \\
\text { and 3D printing. In the } \\
\text { Manufacturing field we also invite } \\
\text { other departments to collaborate on } \\
\text { producing student projects in } \\
\text { Additive Manufacturing, 3D } \\
\text { printing. So, we can say that our } \\
\text { student has an idea about IR4.0 } \\
\text { requirements but need to polish the } \\
\text { competence }\end{array}$ \\
\hline D & $\begin{array}{l}\text { When we refer to the Industrial } \\
\text { Revolution } 4.0 \text {, it means that most } \\
\text { of the management and production } \\
\text { processes in the industry today are } \\
\text { fully utilizing automation system } \\
\text { technology, on the part of our } \\
\text { Ministry we hear a lot about the } \\
\text { Internet of things where our so that } \\
\text { competency students need to come } \\
\text { out with skills in in terms of } \\
\text { multimedia and information } \\
\text { technology and IoT directly }\end{array}$ \\
\hline \multicolumn{2}{|c|}{$\begin{array}{l}\text { Discussion } \\
\text { From the analysis, the student competency needs to } \\
\text { be polished in various aspect. Management of } \\
\text { polytechnic need to work hard to make sure the } \\
\text { student or the graduates that they produced can fulfil } \\
\text { IR4.0 skills and competencies. Student need to } \\
\text { enhance with the pillars of IR4.0 such as automation, } \\
\text { augmented reality, internet of things and the changes } \\
\text { of curriculum silibus need to be form and will fulfil } \\
\text { the requirement needs from industries. The graduates } \\
\text { need to be more innovative and able to have a high } \\
\text { complex cognitive competency, technical } \\
\text { competency and create new competency in dealing } \\
\text { with any potential complications regarding } \\
\text { transformation of future technology. }\end{array}$} \\
\hline
\end{tabular}

2) The effect of the change from the development of this revolution in the field of manufacturing especially in the context of employment involving students or graduates of polytechnics in this field

Table 3 The effect of IR4.0

\begin{tabular}{|c|l|}
\hline Participant & Result \\
\hline A & $\begin{array}{l}\text { With IR4.0, our student } \\
\text { employment opportunities will be } \\
\text { narrowed. Because when running } \\
\text { IR4.0, it automatically reduces the } \\
\text { employees. With the ability of the } \\
\text { current polytechnic, students will } \\
\text { have to compete for IR4.0 with } \\
\text { such a requirement because it is not } \\
\text { enough for the students to meet the } \\
\text { pillar in industry 4.0. So, a solution } \\
\text { to add-ons first in syllabus or } \\
\text { polytechnic should be the initiative } \\
\text { to make it a graduate student for the } \\
\text { form of a student he or she first sits } \\
\text { in finishing school to develop } \\
\text { student skills towards IR4.0. When } \\
\text { we look at the student project, it is } \\
\text { true that the student has already } \\
\text { begun to use the sensor, IOT. The } \\
\text { control element is also the student } \\
\text { mix in the student project. } \\
\text { Automatic we can say that our } \\
\text { student had a readiness about this. }\end{array}$ \\
\hline B & $\begin{array}{l}\text { If everyone started IR4.0, all } \\
\text { automation, all robotics, I could see } \\
\text { that in terms of job opportunities } \\
\text { the semi-skilled workforce would } \\
\text { start to decline because everything } \\
\text { went into automation. So, the } \\
\text { number of workers is decreasing, } \\
\text { everything is controlled by } \\
\text { machines, there are fewer people } \\
\text { will get the job. People who are } \\
\text { capable and competent to handle } \\
\text { such technology will have the } \\
\text { opportunity to get a better job. If he } \\
\text { or she has no competency to control } \\
\text { a computer as an example of } \\
\text { understanding programming where } \\
\text { he is not competent, knowledge is } \\
\text { lacking, so he must compete with } \\
\text { less competent people. Students } \\
\text { must be hardworking to know what } \\
\text { new things they can compete with if } \\
\text { they are not difficult }\end{array}$ \\
\hline
\end{tabular}




\begin{tabular}{|l|l|}
\hline \multicolumn{1}{|c|}{ C } & $\begin{array}{l}\text { It is said that our level of } \\
\text { preparation is due to the } \\
\text { polytechnic of a centralized } \\
\text { university system that is not the } \\
\text { same as other universities. And } \\
\text { when it comes to that level of } \\
\text { readiness, now the incoming staff } \\
\text { has improved since we still have a } \\
\text { diploma-based teaching staff. But } \\
\text { in that position, now that the intake } \\
\text { for the lowest level of lecturers is a } \\
\text { degree and the exposure of the } \\
\text { lecturer to the higher education and } \\
\text { open public know that many are } \\
\text { struggling to go politically ready. } \\
\text { Ready to go. if the staff is ready to } \\
\text { increase their competency to pursue } \\
\text { further studies they should be } \\
\text { prepared. The level of readiness for } \\
\text { me is not quite ready }\end{array}$ \\
\hline $\begin{array}{l}\text { Students need to be converted from } \\
\text { conventional digital learning style } \\
\text { learning but towards student center } \\
\text { learning and students cannot be } \\
\text { spoon fed. Students need to think } \\
\text { on their own, develop their own and } \\
\text { solve the problem themselves. Style } \\
\text { learns also changes and we need to } \\
\text { understand our attitude towards } \\
\text { digital transformation programs, so } \\
\text { students must apply a situation } \\
\text { where they learn not to compete but } \\
\text { to learn to love what they do. Got to } \\
\text { learn about the interest in } \\
\text { manufacturing }\end{array}$ \\
\hline $\begin{array}{l}\text { The effect in future, many of students will work } \\
\text { together not only with machines, but also robots [6]. } \\
\text { They need } \\
\text { collaborative skills will be far more important than } \\
\text { ever. Graduates should acquire their flexibility and } \\
\text { own learning skills to remain relevant in the era of } \\
\text { tapid change. They need to be creative and created }\end{array}$ \\
\hline the effect in future changes.
\end{tabular}

3) The educational system (specifically polytechnic as TVET provider) today ready to face the challenge of the Industrial Revolution 4.0?

Table 4 The changes

\begin{tabular}{|c|l|}
\hline Participant & Result \\
\hline A & $\begin{array}{l}\text { Awareness about IR4.0 are already } \\
\text { exists. We are in the process of } \\
\text { drafting the curriculum according } \\
\text { to the requirements of IR4.0. For } \\
\text { me, the syllabus and the existing } \\
\text { tools are still embedded in old } \\
\text { syllabus. This IR4.0 is relatively } \\
\text { new and we must be prepared with } \\
\text { the IR4.0 facility. First the syllabus } \\
\text { needs to be refined to fit the needs }\end{array}$ \\
\hline
\end{tabular}

formulation of the curriculum should consider the opinion of the industry and lecturer. There are improved courses, but they are still important and relevant to teaching students

Frankly speaking, if I look at the current situation, I think it's still not possible for students to get in environment IR4.0 because now that we look at equipment, we have problems with maintenance. Most of our machines when out of order they will have trouble maintaining equipment. Examples in my place are CNC, wire cut, die sinking, lathe and even milling. But only one machine can be used. How student can get the experience to cut using machine. They don't have an opportunity. Students are exposed to machines in theory. So, when they don't have the practical ability to handle it, the experience is lacking Sometimes they don't have hands on so the students will lose confidence. Sometimes when he goes to industry, he wants to turn ON the machine and he can't operate. When exposed to theory alone I think it is difficult for students to operate the machine. Whereas it should be basic knowledge for the students and that knowledge should be available to the manufacturing students. They need for him to survive in the industry. It's difficult for students to operate him machines. If students know they must survive with manufacturing technology especially involving autonomous robots 


\begin{tabular}{|c|c|}
\hline C & $\begin{array}{l}\text { Before this we did polytechnic } \\
\text { surveys, 1L5G surveys, alumni } \\
\text { surveys and we can say that } \\
\text { post-graduate polytechnic. } \\
\text { Graduates are well-established jobs } \\
\text { but with the advancement of } \\
\text { Information Technology like now I } \\
\text { think if our students are not } \\
\text { competing and it will effect to us } \\
\text { because there are great competitors } \\
\text { like ADTEC, Mara Professional } \\
\text { College sometimes when it comes } \\
\text { to bringing their students to } \\
\text { competitions such as go-karts we } \\
\text { can see that the student can } \\
\text { compete well. So, if we do not } \\
\text { apply this IR4.0 pillars we will miss } \\
\text { it, because when an employer needs } \\
\text { an employee, the added value is an } \\
\text { X-factor before we focus on the } \\
\text { only Soft Skill, Generic Skill } \\
\text { Attribute (GSA). Our GSA is high, } \\
\text { public speaking and high soft skills, } \\
\text { we can look at our students now. } \\
\text { This shows that the implementation } \\
\text { has been successful. We just must } \\
\text { dig into the wow factor now that } \\
\text { our students can fit in with what the } \\
\text { industry needs }\end{array}$ \\
\hline D & $\begin{array}{l}\text { This IR4.0 started in Malaysia } 2015 \\
\text { onwards. If we want to compare } \\
\text { with German technology } 2011 \text { they } \\
\text { are starting but if we look at the } \\
\text { Malaysian context, we have the } \\
\text { opportunity and in } 2015 \text { we created } \\
\text { awareness and } 2016 \text { is on track. } \\
\text { Now that } 2019 \text { is only back } 4 \text { years } \\
\text { ago, I see we've implemented it } \\
\text { from elementary school yet. The } \\
\text { use of robots to use Arduino and we } \\
\text { have implemented from the school } \\
\text { level again. Our students are } \\
\text { exposed. However, we are still in } \\
\text { the early stages because our } \\
\text { facilities are developing with the } \\
\text { IR4.0 requirements. If he continues } \\
\text { to implement IR4.0 from the } \\
\text { school, then of course the } \\
\text { foundation will be stronger. In the } \\
\text { last } 2 \text { years of polytechnics we have } \\
\text { also been involved in. }\end{array}$ \\
\hline \multicolumn{2}{|c|}{$\begin{array}{l}\text { Discussion } \\
\text { Educational systems need to be change due this } \\
\text { transformation. Graduates need to be exposed with } \\
\text { the current technological aspects. In term of } \\
\text { polytechnic management, there need to make an } \\
\text { action in various contexts such as added the value of } \\
\text { resource requirements, educator's knowledge, skills } \\
\text { and training need to be planned to face this } \\
\text { challenge. Indirectly, it will increase the ability of } \\
\text { graduates to address the needs of the future industry. }\end{array}$} \\
\hline
\end{tabular}

Nevertheless, it involves the manufacturing sector which is one of the sectors that contributes to high employment opportunities in future with IR4.0 paradigm [6],[7].

The overall findings from this interview sessions found that there is moderate readiness in program implementation about this IR4.0 element in terms of student competency, the effect of the changes and actions taken by polytechnics management. Student that we trained today will become as human roles for industries in Malaysia. They will work in industries especially in manufacturing sector. The number of employees involved in the manufacturing sector in Malaysia increased by $0.1 \%$ every month beginning November 2014 and has always been increasing [9]. Employment opportunities in the manufacturing sector accounted for 2.1 million workers by 2015 and will be increased in future transformation. This led to the manufacturing sector in Malaysia among the sectors that recorded high employment opportunities. Employment that requires skilled workers is $61.9 \%$ compared to skilled workers of $23.5 \%$ and low skilled workers register $14.5 \%$. This suggests that the graduates in manufacturing industry is really needed as well as for IR4.0 transformation in the industry towards skilled workers in the future industry is very important. This research had study in the Malaysian context that need to implement to find solutions for education line to face of IR4.0 changes.

\section{CONCLUSION}

IR4.0 illustrates the rapidly evolving technology revolution around the world and will change the today education landscape. However, the transformation of IR4.0 in Malaysia is still new and many explorations needs to be adjusted in industries, economics, education, human resources and others. In the context of this study, IR4.0 is intended to obtain the strategy planning and action in the education especially in manufacturing field. The industries that had implement the pillars of IR4.0 in their operations needed to involve in education line and apply IR4.0 milestones in together. This encompasses milestones related to the advancement technological change of the cyber-physical system in manufacturing engineering, the internet of thing, human-robot collaboration, cloud technology, automated systems and large data analytics. It to provide insights and outline the new, up and reskill requirements needed in forming the required competencies and qualities for the students to face the future era. Emphasis will be given to semi-skilled human capital as a Polytechnic student especially in assisting in curriculum implementation, teaching and learning process, resource allocation and suitability of training to be given align with IR4.0 needed.

\section{ACKNOWLEDGMENT}

The author would like to thank Ministry of Education (MOE) for giving great privilege in providing scholarship as inspiring encouragement for the success of this research.

Published By:
Blue Eyes Intelligence Engineering
\& Sciences Publication




\section{REFERENCES}

1. Lai Wan, H. (2016). The Manufacturing Sector in Malaysia. (C) Springer Science+Business Media Singapore 2016, (November 2014), 21-37. https://doi.org/10.1007/978-981-10-0030-0

2. Bunse, B. (2013). Industrie 4.0- Smart Manufacturing for the Future. GTIA- Germany Trade and Invest, 40. https://doi.org/10.1007/978-3-642-36917-9

3. Lorenz, M., Rüßmann, M., Strack, R., Lueth, K. L., \& Bolle, M. (2015). Man and Machine in Industry 4.0., Boston Consulting Group, 18.

4. Baldassarre, F., Ricciardi, F., \& Campo, R. (2017a). The Advent of Industry 4.0 in Manufacturing Industry: Literature Review and Growth Opportunities. DIEM: Dubrovnik International Economic Meeting, 632-643

5. Plouff, C. (2014). Using the Four Pillars of Manufacturing Engineering Model to Assess Cur- ricular Content for Accreditation Purposes Using the Four Pillars of Manufacturing Engineering Model to Assess.

6. Hartmann, E. A., \& Bovenschulte, M. (2014). Skills Needs Analysis for Industry 4.0 Based on Roadmaps for Smart Systems. Using Technology Foresights for Identifying Future Skills Needs. Global Workshop Proceedings., 24-36.

7. Zhong, R. Y., Xu, X., Klotz, E., \& Newman, S. T. (2017). Intelligent Manufacturing in the Context of Industry 4.0: A Review. Engineering, 3(5), 616-630. https://doi.org/10.1016/J.ENG.2017.05.015

8. Lebar, O. (2012). Penyelidikan Kualitatif: Pengenalan kepada teori dan metod. Penerbit Universiti Pendidikan Sultan Idris

9. Jabatan Perangkaan Malaysia. (2018). Statistik Utama Tenaga Buruh di Malaysia, Januari 2018. Statistics of Graduates in the Labour Force Malaysia. https://doi.org/2289-3083

\section{AUTHORS PROFILE}

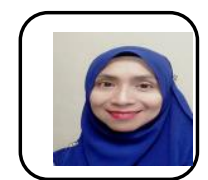

First Author Nurul Afizah binti Adnan is a student in Faculty Technical and Vocational, University Tun Hussein Onn Malaysia in PhD level. Her experience as a lecturer in Mechanical Engineering for Polytechnic institute for over 10 years before achieved the scholarship from Education Ministry for continue study.

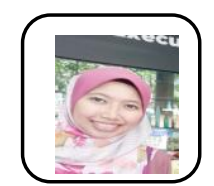

Second Author Aini Nazura Paimin is a lecturer in Faculty Technical and Vocational University Tun Hussein Onn Malaysia. Her research interests include technical and vocational and engineering education. She actively involved in curriculum development project and is currently teaching mechanical engineering subjects at the Faculty of Technical and Vocational Education

Third Author Abdullah Azraai Hasan is a student in Faculty Technical and Vocational, University Tun Hussein Onn Malaysia in Master level. Her experience as a lecturer in Information Technology for Polytechnic institute for over 10 years before achieved the scholarship from Education Ministry for continue study. 